\title{
Historical commons as sites of transformation. A critical research agenda to study human and more-than-human communities
}

\author{
Marta Nieto-Romero ${ }^{\mathrm{a}, \mathrm{b}, *}$, Sandra Valente ${ }^{\mathrm{c}}$, Elisabete Figueiredo ${ }^{\mathrm{a}}$, Constanza Parra ${ }^{\mathrm{d}}$ \\ ${ }^{a}$ Department of Social, Political and Territorial Sciences, Wageningen University, University of Aveiro, Portugal \\ ${ }^{\mathrm{b}}$ Department of Social Sciences, Wageningen University, the Netherlands \\ ${ }^{\mathrm{c}}$ Department of Environment and Planning, University of Aveiro, Portugal \\ ${ }^{\mathrm{d}}$ Department of Earth and Environmental Sciences, University of Leuven, Belgium
}

\section{A R T I C L E I N F O}

\section{Keywords:}

Commoning

Institutions

Community

More-than-human

Transformation

Sustainability

\begin{abstract}
A B S T R A C T
The most critical question for sustainability research is how to facilitate transformative change. Yet, the academic scope of historical commons' research is limited to institutional design and environmental sustainability. In this paper we argue for a transformative research agenda for historical commons focused on the study of processes building humans and more-than-human communities. We start by reviewing three commons schools, namely the mainstream and critical institutionalism and the community economies collective, and assess how these relate to sustainability and to theories on agency, community and change. We then define a research agenda taking a political and critical ontology of the community economies collective, and a phenomenological epistemology of critical institutionalism. We follow by characterising the underlying practices building humans and more-than human communities by showing three ideal stages of commoning found in our empirical cases in the north-western Iberian Peninsula (Spain and Portugal). Finally, we end by presenting a guiding framework for analysing processes of building communities in historical commons. In conclusion, we encourage further exploration of underlying practices that widen humans' interdependency and inter-being and call for action-research projects and experimental methods that promote transformative encounters between humans and nature. Our framework is a first attempt to inspire researchers of historical commons to actively engage in unravelling the full potential of historical commons as sites of transformation.
\end{abstract}

\section{Introduction}

Historical commons, referring to the familiar commons of history revolving around multifunctional plots of land, with arable land, grasslands, shrublands or/and woodlands, or with other natural resources, such as water or fisheries have inspired much of the contemporary research in commons. However, while other types of commons such as social, business or digital commons (see Bollier, 2014: 133) have transcended Ostrom's views of what commons mean and serve for, - e.g. Time Banks (Diprose, 2016), Ecovillages (Esteves, 2016), Community Supported Agriculture (Vivero Pol, 2015), or open source software projects (Barron, 2013; Bradley, 2015) - historical commons research seems to remain anchored to a scope of ecosystem management which defines commons as a collective property system or even as common-pool resource systems (Alló and Loureiro, 2016; Caballero, 2015; Domínguez García et al., 2014; Gómez-Vázquez et al.,
2009; Grupo dos Comúns, 2006; Lopes, 2008; Marey-Pérez et al., 2010). A transformative research agenda requires that historical commons' research go beyond ecosystem management and be studied under the lens of larger sustainability transformations (Blythe et al., 2018; Göpel, 2016; O’Brien and Sygna, 2013; Popa et al., 2015).

The UNEP (2012), among others (see Göpel, 2016; O'Brien and Sygna, 2013), has claimed that sustainability transformation is beyond rules and incentives, and that only a change of human systems of meaning, mindsets, worldviews and subjectivities can bring the scale of change needed for the so-called Anthropocene. Capra and Mattei (2015), Gibson-Graham and Roelvink (2010), Haraway (2010) and Rauschmayer (2017), among others, argue that the key worldview deeply responsible of the Anthropocene is the belief that humans are autonomous individuals, separated from each other, as well as from nature and other conditions of their existence. Challenging this worldview implies questioning the "deeply embedded premises of our

*Corresponding author at: Campus Universitário de Santiago, Department of Social, Political and Territorial Sciences, University of Aveiro, 3810-193 Aveiro, Portugal.

E-mail addresses: marta.nietoromero@wur.nl (M. Nieto-Romero), sandra.valente@ua.pt (S. Valente), elisa@ua.pt (E. Figueiredo), constanza.parra@kuleuven.be (C. Parra). 
[economic and political] systems" (Bollier, 2014: 147). Any management or governance intervention that does not challenge this underlying subjectivity will continue reproducing the 'business-as-usual' system (Göpel, 2016). We see commoning as one way to challenge this system.

Commoning strengthens and widens the sociality of human beings among themselves and with other non-humans and nature (Parra and Walsh, 2016), enhancing humans to feel and behave collectively in an inter-related way with other human (Fournier, 2013; Sandström et al., 2017) and non-human species (Bresnihan, 2015; Gibson-Graham et al., 2016b). This subjectivity has been referred to as "inter-being" (Rauschmayer, 2017). When nurturing inter-dependency, humans form communities of humans and non-humans (Gibson-Graham et al., 2016b; Singh, 2018). To our knowledge there are few studies exploring changes in subjectivities in historical commons (Agrawal, 2005; Nightingale, 2011; Sandström et al., 2017; Singh, 2018, 2013), despite the fact that it is the cornerstone for any sustainability transformation. In most research on historical commons, cohesive communities are seen as a "tool" or incentive to achieve environmental and social sustainability. Instead, in this paper communities are seen as both the "tool" and the "objective" of environmental and social sustainability. To build communities is an end in itself, which, as seen above, relates to a subjectivity of inter-being and thus has transformational potential. As stated by Stephen Gudeman: '[W]ithout a commons, there is no community; without a community, there is no commons' (Gudeman (2001:27) in Gibson-Graham et al., 2016a: 196). Yet, to our knowledge, there is a lack of comprehensive descriptions of the underlying patterned practices that describe human and more-than-human communities. Without a more explicit characterization of communities, it is difficult to critically assess how and to what extent commoning manages or not to build these communities.

This paper explores theories on commons and sustainability to define a transformative research agenda for historical commons. The paper theoretically and empirically explores the role of historical commons in creating human and more-than-human communities and describes the practices behind them. Our main argument is that by studying processes of challenging the dominant subjectivities of separateness, we can go beyond informing ecosystem management in historical commons. This type of research can potentially strengthen embryonic communities and promote the creation of new ones (GibsonGraham et al., 2016a).

The following section starts by reviewing three commons schools the mainstream institutionalism (MI), the critical institutionalism (CI) and the community economies collective (CEC) - exploring how these three schools understand commons in relation to sustainability, and the theories on agency and community used to look at commons dynamics. From this literature review, we conclude that a transformative research agenda for historical commons needs a CEC ontology and a CI epistemology. In order to do so, a view of agency as relational and institutions as patterned practices needs to be adopted. Section three mobilizes empirical material generated as part of an EU Horizon 2020 Marie Curie ITN project SUSPLACE (April 2016-March 2019). We use data from historical commons located in Northern Portugal and North-western Spain to illustrate and substantiate our theoretical arguments, notably to characterize human and more-than-human communities based on underlying commoning practices. Section four builds upon this characterization of communities to build a framework to guide the task of critically studying processes of building human and more-than-human communities. This framework gives an original commoning definition for historical commons and highlights important practices building communities. In the conclusion section, we argue that our framework can enhance a critical and potentially transformative research agenda in historical commons, and we call for empirical studies that further expand our knowledge on the type of practices involved in building human and more-than-human communities and of experimental methods that promote them.

\section{Historical commons and commons theories}

\subsection{The sustainability problem of the commons}

Historical commons existed in Europe since the Middle Ages, a period when many territories had lands that were used or managed by communities (Bravo and De Moor, 2008; Lopes, 2014). Historical commons, also referred to as common lands when involving land held in common, provided specific communities with the natural resources they needed to make their living (De Moor, 2011). These rights started to be abolished at the end of the 18th century, when ideas of the Industrial Revolution and the virtues of private property permeated the organization and legislation of the territory (Bravo and De Moor, 2008). Only a few historical commons remain till present day and these are formally regulated through legal frames instituted during the 20th century. Beyond customary rights, legal frames suggest specific rights and duties for using and benefiting from these lands as a community (e.g. Bryden and Geisler, 2007; Caballero, 2015; Kluvánková-Oravská and Chobotová, 2006; Mantescu and Vasile, 2009; Paletto et al., 2012; Premrl et al., 2015).

Most research in historical commons makes use of the theories within mainstream institutionalism (MI) and critical institutionalism (CI). For both MI and CI, commons' resource systems are defined as collective property rights regimes (Table 1 ), resource systems where communities have the power to exclude outsiders from the use of the resource system (Table 1). Elinor Ostrom was the first to define these as different from an open access system where excludability is absent or very difficult (Schlager and Ostrom, 1992). Although MI and CI differ substantially in their theories on agency and communities (see Section 2.2 ), they both rely on studying the management of ecosystems - and their inner working and outcomes in terms of environmental sustainability or community well-being (e.g. Ostrom, 2005; Cleaver, 2012; Arts et al., 2013; Mcginnis, 2014).

MI seeks to provide answers for sustainable ecosystem management, highlighting that unspecified or ill-designed institutions (in regard to elements such as access or use and management) are the main problems for sustainable management (Table 1). Thus, MI research results in principles that guide institutional crafting for balancing humans' tendency to maximize individual material gains, reduce uncertainty and foster reciprocity and trust for the sustainable management of ecosystems (Cox et al., 2010; Ostrom, 1990) (Table 1). In parallel to the development of MI, CI was born as an alternative claiming that institutions cannot be strategically redesigned (Cleaver, 2012; de Koning and Cleaver, 2012; Hall et al., 2013). Instead, CI research shows the variety of outcomes delivered by institutions looking at historical politicaleconomic contexts, larger socio-political dynamics and invisible workings of power affecting access to resources (Table 1) (e.g. Cleaver and De Koning, 2015; Cleaver and Franks, 2005; de Koning and Cleaver, 2012; Ribot and Peluso, 2009).

Later on, and influenced by the advances of resilience thinking and social-ecological systems (i.e. Folke, 2006; Olsson et al., 2006; Walker et al., 2009), MI engaged with the study of the dynamics of socialecological systems (Ostrom, 2009). The focus remained on ecosystem management and was criticized for being apolitical (Diprose, 2015; Kaika, 2017), anthropocentric, focused exclusively on human needs and agency (Herman, 2016), and for not challenging important deep structures of thought (i.e. the separation between humans and nature) (Gibson-Graham et al., 2016b).

For the Community Economies Collective (CEC), commons are not resources systems nor property rights regimes. For the CEC, any material or immaterial resource within the environment (such as water, air, food, etc.) or within the community (such as knowledge, language, cooperation and information), can potentially be widely used and (re) produced for the sustenance of life (Bollier and Helfrich, 2012). Thus, commons are understood better as "commoning", as a process of negotiation - or more often a struggle - of access, use, benefit, care, and 
Table 1

Research within the three schools on commons. The sections highlighted in grey refer to concepts that support a transformative research agenda for historical commons.

\begin{tabular}{|c|c|c|c|}
\hline Some references: & $\begin{array}{l}\text { Mainstream Institutionalism } \\
\text { (MI) } \\
\text { Dietz, 2003; Cox, 2010; McGinnis, 2014; } \\
\text { Ostrom, 1998, 2005, 2009 }\end{array}$ & $\begin{array}{l}\text { Claver, 2012; Hall, et al. 2010; McCay, 1998; } \\
\text { Ribot \& Peluso, 2009, Whaley, } 2018\end{array}$ & $\begin{array}{l}\text { Community Economies Collective } \\
\text { (CEC) } \\
\text { Graham-Gibson,2016; Bollier, 2014; Fournier, } \\
\text { 2013; De Angelis and Harvie, 2014; Singh, } 2018\end{array}$ \\
\hline $\begin{array}{l}\text { Definition of } \\
\text { Commons: }\end{array}$ & \multicolumn{2}{|c|}{$\begin{array}{l}\text { A type of property right regime, a property system used in common with } \\
\text { others, where users are co-equal in their rights to use, manage and exchange } \\
\text { their rights towards the resource. }\end{array}$} & $\begin{array}{l}\text { It is commoning, a dynamic process of } \\
\text { negotiating the rules for producing and } \\
\text { reproducing commons resources for all. }\end{array}$ \\
\hline $\begin{array}{l}\text { Sustainability } \\
\text { problem attributed } \\
\text { to: }\end{array}$ & $\begin{array}{l}\text { Imperfect or ill-designed institutions } \\
\text { affecting resource access and } \\
\text { environmental sustainability. }\end{array}$ & $\begin{array}{l}\text { The historical and broad political- } \\
\text { economic context, social dynamics } \\
\text { and power, affecting resource access } \\
\text { and environmental sustainability. }\end{array}$ & $\begin{array}{l}\text { Capitalism, which uses and encloses the } \\
\text { commons, including nature. This political- } \\
\text { economic paradigm is responsible for the } \\
\text { Anthropocene. }\end{array}$ \\
\hline Researcher's role: & $\begin{array}{l}\text { To predict/propose new crafted } \\
\text { institutions to improve outcomes } \\
\text { (environmental \& social sustainability) }\end{array}$ & $\begin{array}{l}\text { To identify why outcomes occur in } \\
\text { each context (providing only an } \\
\text { explanation, sustainability is not the } \\
\text { direct focus) }\end{array}$ & $\begin{array}{l}\text { To identify, propose and strengthen } \\
\text { embryonic commoning-communities } \\
\text { (action research projects focused on } \\
\text { transformative change for sustainability) }\end{array}$ \\
\hline Agency: & $\begin{array}{l}\text { Bounded rationality, seeking } \\
\text { individual benefits (but are fallible, } \\
\text { have different preferences and } \\
\text { strategies). Collaboration and } \\
\text { competition exist. }\end{array}$ & $\begin{array}{l}\text { Agency is relational. Individuals are } \\
\text { guided by embodied, moral, } \\
\text { emotional or social rationalities. } \\
\text { Collaboration and competition exist. }\end{array}$ & $\begin{array}{l}\text { Agency is relational. Individuals are } \\
\text { relational emergences responding to the } \\
\text { world. They tend to cooperate, although } \\
\text { anxiety, struggle and conflict are inherent } \\
\text { to negotiations. }\end{array}$ \\
\hline $\begin{array}{l}\text { Defintion of } \\
\text { Community: }\end{array}$ & $\begin{array}{l}\text { Local, bounded to a territory, and } \\
\text { defined by the aggregation of } \\
\text { individual actors' behaviours (Local } \\
\text { community) }\end{array}$ & $\begin{array}{l}\text { Built through interactions } \\
\text { maintaining shared beliefs and values } \\
\text { (Identitarian community) }\end{array}$ & $\begin{array}{l}\text { Built through interactions maintaining } \\
\text { relations of being-in-common } \\
\text { (Interdependent and more-than-human } \\
\text { community) }\end{array}$ \\
\hline $\begin{array}{l}\text { Actions that bring } \\
\text { change: }\end{array}$ & $\begin{array}{l}\text { Commoners' strategically design } \\
\text { institutions for collective action } \\
\text { (Institutional design) }\end{array}$ & $\begin{array}{l}\text { Commoners' piece together different } \\
\text { arrangements via conscious and } \\
\text { unconscious everyday practices } \\
\text { (Institutional bricolage) }\end{array}$ & $\begin{array}{l}\text { Commoners' engage voluntarily and } \\
\text { morally in negotiations of co-existence }\end{array}$ \\
\hline
\end{tabular}

responsibility for the wide and shared benefit of communities (GibsonGraham et al., 2016a). The CEC claims that the sustainability problem lies in the current economic paradigm which, through private property and individual capital accumulation, encloses the commons that are essential for humans (Capra and Mattei, 2015; Mattei, 2012). It is through commoning that resources- either under a private, public or common property regime- can become a system favouring wealth for humans and non-humans. Commoning (re)produces a social organization system formed by communities of users and producers defining modes of use, production and circulation of these resources (De Angelis and Harvie, 2014; Euler, 2018).

Understanding commons as practices of commoning allows for seeing the commons as something that occurs here and now, anytime humans voluntarily self-organize to take responsibility and care of shared resource- e.g. via unpaid housework, volunteering, practices of neighbourhood associations, etc. - and thus, as something that can be promoted and strengthened (Bollier, 2016; Euler, 2018; Safri, 2015). The CEC's research goal is not to explain but to identify, propose and strengthen commoning processes through proposing new and wider relations via action research projects (Table 1) (e.g. Cameron et al., 2014; Diprose, 2016; Safri, 2015). Through this, the CEC opens a new research agenda beyond ecosystem management directed to tackling the underlying reasons of the unsustainability of the Anthropocene (Gibson-Graham, 1996; Gibson-Graham and Roelvink, 2010).

Commoning for the CEC consists of a "different way of seeing and being" (Bollier, 2014), and of a "transformative paradigm" (Bollier, 2016) supporting greater participatory control over shared resources and community life. Thus, the CEC ontology, which understands commons as commoning, transforms commons research into a political and critical project for promoting sustainability transformations (Jhagroe, 2018; Kemmis et al., 2014a). Looking at processes of commoning is political and critical. Commoning highlights that any type of resource can be commoned and any person, including researchers, can participate in commoning processes; it also defines the unsustainability problem as the responsibility of an economic-political system that encloses shared resources via privatization and marketization (Table 1).

\subsection{Theorizations on agency and communities}

MI developed a theory of agency in which commoners are capable of self-organizing and devising norms and rules to produce common goods (Ostrom, 1990). This was revolutionary at a time where other collective choice theories (e.g. Hardin, 1968; Olson, 1965) portrayed humans as rational and self-interested, and supported the need for external coercion mechanisms of the market or state. Yet, the MI approach is still based on rational choice theory: humans are still understood as seeking to maximize material benefits, yet bounded to available information and embedded in contexts shaping their individual costbenefit calculus (Ostrom, 2005). The rational assumption has normative and political implications. By not taking historical and broad political economic contexts into account, MI usually blames local actors and institutions for undesirable developments, and suggests "institutional fixes" to communities even if local institutions were not the problem in the first instance (McCay and Jentoft, 1998). Instead, CI and the CEC schools look at commoners in relation to social, political and historical trends of society at large to understand that most of the time commoners are victims of larger socio-political struggles over resource enclosures and development paradigms rather than responsible of resource depletion (Gibson-Graham et al., 2016a; Goldman, 1998; Saunders, 2014). Although both CI and the CEC share this political view on the commons, they build upon different theoretical grounds for understanding agency and communities.

Both CI and the CEC schools understand agency as relational. Yet, while CI looks at how (community) relations drive individuals' actions, the CEC focuses on individuals' processes of becoming via their relationality to others, humans or non-humans. That is, following philosophers such as Bruno Latour, Nancy Jean-Luc, Val Plumwood or Gilbert Simondon, the CEC looks at processes of co-constitution and cobecoming arising with the sole experience of being in relation to others (Diprose, 2016; Gibson-Graham, 2006; Gibson-Graham and Roelvink, 2010; Roelvink and Gibson-Graham, 2009; Singh, 2018). The self is not seen as an autonomous subject acting in the world, but as a relational emergence responding to the world (Singh, 2018), questioning the 
principle of individuality of Western philosophy (Read, 2015 as cited in Singh, 2018).

Contrarily, CI acknowledges individuality but provides models of agency that recognize humans as driven by their relations to others and thus following 'emotional' 'moral' or 'social' rationalities beyond the economic (Cleaver and De Koning, 2015; de Koning and Cleaver, 2012; Whaley, 2018); humans are unconsciously guided by community norms, moral worldviews, relations of care, power dynamics, emotions and other physical embodied experiences (Agrawal, 2005; Cleaver, 2012; Lejano and Castro, 2014; Peters, 2004; Singh, 2013). Accordingly, CI also defines communities relationally: that is, built through social interactions and networks of communication which generate a community with shared norms, explanations and values (Table 1), and bring forward a notion of community based on shared identity forming an 'integrated whole' (Durkheim 1964 as cited in McCay and Jentoft, 1998).

The CEC also defines a community relationally yet not based on a uniform identity. A community is diverse, open and ever-evolving (Diprose et al., 2017). Membership is not based on identity but on "appropriate use", that is, a community involves all those willing to respect and negotiate the appropriate use of resources for their collective material and cultural survival (Diprose et al., 2017; Fournier, 2013). As Gibson-Graham (2006: 99) states, "a community involves those that engage in the ethical negotiations of co-existence for their economic being-in-common." The process of building community is driven by humans' intrinsic will to build meaningful social relations, yet this brings forth anxiety, conflict and struggle (Diprose, 2016; GibsonGraham et al., 2016a) (Table 1). Negotiations involve humans and nonhumans (see Bresnihan, 2015; Gibson-Graham et al., 2016b). For the CEC, agency includes the non-human world - e.g. growth, the reproductive cycle, etc. (Bresnihan, 2015; Ruivenkamp and Hilton, 2012)- and as such, investigates how non-humans indirectly participate in negotiations via their affects on humans (Bresnihan, 2015; Singh, 2018, 2013). For example, the longer cycles of growth and decay in trees can link people to the past and the future, fostering the inclusion of inter-generational responsibility and sustainability concerns in decision-making and management (Herman, 2016).

As stated earlier, we argue that a transformative research agenda for historical commons needs a CEC ontology, including its approach to agency and community theorizations. An ontology based on CEC means accounting for the co-constitutions of the self and the community via relational processes, including relations to non-humans, which also involves the effect that relations have to individual's actions. This ontology allows studying commoning as processes of building human and more-than-human communities. For the CEC, communities are relational, diverse, human and more-than human. This contrasts with the legal frames regulating historical commons which pre-define who is part of a community and its commoning negotiations- i.e. those living in a particular parish (Caballero, 2015) or municipality (Paletto et al., 2012), belonging to a genealogic group (Le Tourneau and Beaufort, 2017), or possessing land or other means (e.g. cattle) to use the resources system (Sanchis-Ibor et al., 2017; Sutcliffe et al., 2013). Yet, a CEC ontology allows to distinguish legal commoners, defined by law, from those commoners in practice, practicing commoning and forming communities. Legal commoners need to become commoners (see Singh, 2018), meaning subjects who see the environment and the community as a commons, and engage in commoning for their cultural and material survival. The question remains in regard to how exactly this new subjectivity occurs: how can legal commoners come to realize their interdependence or sense of being-in-common with other humans and nonhumans and behave as part of human and more-than-human communities? In the next section we explore how CI can help answering this question.

\subsection{Critically studying human and more-than-human communities}

This section uses CI institutional theory to describe human and more-than-human communities as built by institutions. The institutional theory of CI is based on practice theory, which understands tangible practices as the building blocks constituting the social (Schatzki et al., 2001). For CI, institutions are not external "things" (structures) affecting behaviour (agency), as portrayed by MI; institutions are instead dynamic and fuzzy assemblages of meaningful practices (Cleaver, 2012: 45), or practical "ritual mechanisms" (Douglas, 1986), that maintain and recreate social relations. Practices are more than just actions, but refer to a repeatable set of doings, supported by particular sayings, or understandings of the world, that create particular relations (Schatzki et al., 2001 as cited in Kemmis et al., 2014b). Thus, institutions do not affect commoners but are themselves animated by commoners' actions.

In line with Lejano et al. (2018), a view of institutions as practices is phenomenological: that is, it aspires to describe phenomena of how 'institutions appear to us' in their most genuine and faithful way. This view does not deny the power of strategic discourses and recognizes precognitive patterns of unconscious actions as shaping social construction (Lejano et al., 2018). This phenomenological approach allows to bridge otherwise separate fields, CI and the CEC schools, by understanding commoning as a process of institutional bricolage (e.g. Sandström et al., 2017). CI defines institutional emergence and change as processes of institutional bricolage. Institutional bricolage puts forward that institutions cannot be rationally crafted or designed, as they are the result of adaptive every-day practices through which actors creatively piece together different arrangements. Institutions are both the result of planned or improvised, conscious or unconscious action, and result from individuals patching together the social, cultural and political resources available to them based on the logic of dynamic adaptation (Cleaver and De Koning, 2015; de Koning and Cleaver, 2012).

This paper combines a CEC ontology with a CI epistemology via understanding agency as relational and institutions as the patterned practices building commons and communities (see shaded cells in Table 1). We argue that commoning, as the ongoing set of social practices, such as negotiation, mutual support, conflict, communication and experimentation, can be better understood in light of institutional bricolage. Commoning is not fully strategic nor fully unconscious; it is driven by moral and social relationalities, but is also shaped by unconscious actions that reproduce a certain social order. Institutions confer stability while they are in permanent change through strategic behaviours, improvisation and adaptations. By identifying the institutions underlying human and more-than-human communities, researchers can analyse commoning progress. To do so, in the following section we explore how practices of commoning relate to community formation.

Commoning has been defined in numerous ways (e.g. Bollier and Helfrich, 2015; Euler, 2018; Gibson-Graham et al., 2016a; Ruivenkamp and Hilton, 2012; Swan and Cooper, 2013). For our study, we consider the three types of commoning practices identified by Fournier (2013): practices assuring resources are shared in common, are used for the commons and are producers of the common. We argue that these three dimensions of commoning practices help characterize the practices building human and more-than-human communities. First, commoning is a set of practices that assures that resources are shared in common. This involves all practices that allow the allocation of common resources to individual members. For example, in the famous commons case of Maine (USA) (see Schlager et al., 1992), commoning practices involve negotiating the permitted places to fish and the amount of catches allowed for each fisherman. Thus, practices within this dimension are related to dividing the common pie among individual appropriators for an equitable and fair access to resources (i.e. decisionmaking on rules for individual appropriation and practices of 
appropriation themselves).

A second dimension of commoning includes using resources for the common (Fournier, 2013), that is, for the community as a whole. For example, in the urban commons of Can Masdeu (Barcelona) (see Fournier, 2013), commoning practices involved producing but also cooking and eating food together; producing and consuming knowledge and skills (of organic gardening, building techniques, baking and so on) with the community of residents or, through the free workshops, with the broader public. Common resources were not allocated individually but were consumed for the common.

Finally, the third dimension of commoning refers to the production of resources of the commons. Commoning not only involves the allocation and collective consumption of resources, but most importantly the production (and reproduction) of commons resources. For example, Singh (2018) explains that practices in a common land in India- of patrolling forests, picking up dead and dried wood, etc.- nurtured commoners' capacities to act and respond in forests as a community. These practices produced knowledge of the plants that grew in forests and their use for subsistence, or of which trees should be grown or felled for timber, as well as the social relations necessary to take care of the forests by the joyful experiences with other humans (Fournier, 2013; Singh, 2018). They were producers of resources of the commons. In other words, by the act of "economic being-in-common" (GibsonGraham, 2006), commoning (re)produces material resources (such as wood, crops, fish, etc. when (re)planting or respecting periods of closed fishing) and immaterial resources (such as the networks of solidarity and reciprocity building a community, its skills, knowledge, etc.).

Commoning, with its three dimensions, can nurture a different mode of humanity (Plumwood, 2007: 1 as cited in Gibson-Graham and Roelvink, 2010), a new sociality or a new subjectivity that replaces the market rationale with the rational of human and more-than-human communities (Singh, 2018). This logic emerges from practices that produce a sense of interdependence and being-in-common with the rest of the world (Duffy et al., 2018; Singh, 2018). Feelings of being-incommon dim the boundaries between what defines the self, the individual, and 'the other', as other humans or non-humans affect the self (Haraway, 2010). Thus, analysing and promoting the formation of communities imply going beyond exploring practices of decisionmaking; to do so includes exploring all practices of socialization and interaction among humans and non-humans- like collective working, consumption of goods, festivities, etc.- which can support changes in subjectivities (Bollier, 2016; Fournier, 2013; Linebaugh, 2008; Sandström et al., 2017).

\section{Commoning to build human and more-than-human communities}

This section examines the practices building human and more-thanhuman communities, by providing examples from four real historical commons in the North-western Iberian Peninsula. For this, we draw on Fournier's commoning dimensions (practices in common, for the common, and of the common) considering them as the institutions, as practices, building communities. We follow Kemmis et al. (2014b,a), who describe practices as action-though complexes composed by sets of sayings, doings and relatings to characterize three types of ideal legal communities: household economy, human interdependent community and more-than-human community (Table 2). These three types of legal communities can be understood as three stages of commoning in historical commons. We discuss how each of the three stages relates to changes in subjectivities, in order to illustrate the transformative effects of human and more-than-human communities.

\subsection{Historical commons at North-western Iberian Peninsula}

At the beginning of the 20th century, northwest Spain and the centre and north of Portugal had one of the largest surfaces of common lands in Europe. These common surfaces were a remnant of a Germanic property regime, dating back to the Middle Ages (see Lana, 2013), in which all neighbours in the parish enjoyed access to resources as long as they lived in the area. De facto informal rules, decided through community assemblies, set up the stage of accepted uses. Common lands were used at a household level and were key for family livelihoods, as a complement to traditional agricultural activities. The land had a multifunctional use, with forests, shrublands and pastures, and uses involved family livestock raising and collection of basic goods, such as firewood for heating and cooking, manure to fertilize cereals fields, herbs, etc. (Baptista, 2010; Grupo dos Comúns, 2006).

A large part of the production and consumption of resources was collective. For example, shepherding was organized in a collective traditional system of vezeiras (in English, "shifts"). Similarly, potato or corn growing occurred on private land, but harvesting was collectively organized in exchange for a meal. Thus, although families held the means to access resources (e.g. land, cattle), collective work and consumption reproduced the networks of communication and social relations underlying communities. Using Fournier's classification, practices to use resources for the commons maintained alive a human interdependent community (see shaded row in Table 2).

The Spanish and Portuguese military regimes (1936-1975 and 1926-1974, respectively) promoted the enclosure of historical commons. The traditional land use was replaced by Maritime pine and eucalyptus plantations for wood and paper pulp (Rico Boquete, 1995; Serra et al., 2015), leading to the eviction of peasants from their historical lands. This contributed to a profound rural transformation and a rural-urban migration also stimulated by the development of new industries and labour force demand in the country and in Europe (Serra et al., 2015; Veiras and Soto, 2011). After the military regime, common lands were devolved to the people and the first Common Land Law was passed.

This restitution of rights arrived within a transformed context (e.g. new laws, the opening of rural economies to global markets and common lands forestation by the military regimes) and at a time when communities did not have the old relations and capacities of interdependency (Baptista, 2011; Grupo dos Comúns, 2006). As a result, despite the recognised rights, most communities did not want to take responsibility of common lands. Due to this, the Common Land law created the possibility of managing common land in partnership with the state. In any case (with or without partnership with the state ${ }^{1}$ ), the legal community have to vote for a governing board (with president, vice-president, treasurer and assembly's convenor) responsible for convening and facilitating two annual assemblies gathering all representing commoners (one per family).

In the case that communities partnered with the state (the majority), the forestry state service continued exploiting wood as done during the military regime. Yet, in this case the State share part of the wood revenues with the legal community. The governing board of the community is responsible for monitoring the accounts and for informing all legal commoners of the financial records; all legal commoners decide through assemblies what to do with the earnings (e.g. some would divide it per household, others would invest it in social infrastructures such as roads or schools). When commoners accepted total responsibility of the common land, the governing board meet monthly for organizing different activities, administers the accounts, and convene representing commoners to assemblies (at least twice per year). At the assemblies, the governing board informs the commoners of the annual accounts, while the assembly vote on proposals brought forward by the governing board.

Below we discuss present-day commoning processes in four

\footnotetext{
${ }^{1}$ In Portugal there is still a third "way" by which the parish government takes total responsibility of the common land. In this case, commoners don't have any power and there is no governing board nor commoners' assemblies.
} 
Table 2

Three stages of commoning in historical commons and a characterisation of underlying practices of human and more-than-human communities.

\section{Practice and Outcome}

Sayings

Doings
Relatings

\begin{tabular}{|c|c|c|c|}
\hline $\begin{array}{l}\text { Resources shared in } \\
\text { common: household } \\
\text { economies }\end{array}$ & $\begin{array}{l}\text { Resources to satisfy } \\
\text { individual/household } \\
\text { needs. } \\
\text { Common lands are a } \\
\text { storehouse of } \\
\text { resources to be sold. }\end{array}$ & $\begin{array}{l}\text { Collective } \\
\text { allocation: general } \\
\text { assemblies, } \\
\text { decision-making } \\
\text { for defining rules } \\
\text { for use and } \\
\text { management. }\end{array}$ & $\begin{array}{l}\text { Vertical relations } \\
\text { between households and } \\
\text { market/state. } \\
\text { Conflicts and mistrust } \\
\text { among households. } \\
\text { Market and state } \\
\text { dependence. } \\
\text { Excludability. }\end{array}$ \\
\hline $\begin{array}{l}\text { Resources for the } \\
\text { common: } \\
\text { a human } \\
\text { interdependent } \\
\text { community }\end{array}$ & $\begin{array}{l}\text { Resources to satisfy } \\
\text { community needs. } \\
\text { Common lands are } \\
\text { the means to produce } \\
\text { and reproduce a } \\
\text { community. }\end{array}$ & $\begin{array}{l}\text { Collective } \\
\text { production, use } \\
\text { and reproduction: } \\
\text { collective work } \\
\text { and meals, shared } \\
\text { knowledge, etc. }\end{array}$ & $\begin{array}{l}\text { Horizontal relations } \\
\text { between households. } \\
\text { Reciprocity and } \\
\text { solidarity relations. } \\
\text { Market and state } \\
\text { independence. } \\
\text { Inclusiveness. }\end{array}$ \\
\hline $\begin{array}{l}\text { Resources of the } \\
\text { common: a more- } \\
\text { than-human } \\
\text { community }\end{array}$ & $\begin{array}{l}\text { Resources are to be } \\
\text { shared with other } \\
\text { humans and non- } \\
\text { humans. } \\
\text { Commoners belong } \\
\text { to common lands. }\end{array}$ & $\begin{array}{l}\text { Collective } \\
\text { regeneration (of } \\
\text { the self, the } \\
\text { community and } \\
\text { the environment): } \\
\text { practices of care. }\end{array}$ & $\begin{array}{l}\text { Horizontal relations } \\
\text { between households and } \\
\text { with non-humans. } \\
\text { Transformation. } \\
\text { Inclusiveness. }\end{array}$ \\
\hline
\end{tabular}

historical commons: Teis (Pontevedra, Spain), Ramallosa (Pontevedra, Spain), O Carballo (Lugo, Spain) and Ansiães (Porto, Portugal). We draw attention to these commons because the four started commoning at different times: that is, they broke the partnership with the state and started negotiations for taking responsibility and care of their common lands by themselves. Ramallosa and Teis started commoning during the 90s, O Carballo in 2006 and Ansiães in 2016. Also, the commons are affected by different rural-urban drivers of change (e.g. urban sprawl vs. rural abandonment) and have different legal frameworks (Spanish vs. Portuguese). We base our discussion on fieldwork research conducted from November 2016 to July 2018 and comprised of 61 semistructured interviews with commoners, key actors at the regional and national level of the regional or national common land organizations, and government representatives from the local and provincial levels. We use excerpts from these interviews to illustrate three theoretical stages of commoning in historical commons.

\subsection{Processes of building communities: three stages}

\subsubsection{Resources in common build a household economy}

We define a first stage of commoning as characterized by a legal community formed by individual household economies maintained by practices to share resources in common. In line with other literature (e.g. Marey-Pérez et al., 2014; Le Tourneau and Beaufort, 2017), our cases show how formal laws giving property rights, together with practices to manage resources in common (e.g. decision-making for defining uses and rules) are not enough to build communities and assure environmental sustainability. We have seen this to some extent at O Carballo and Ansiães cases. We describe below the underlying sayings, doings and relatings of these two cases.

Many commoners in both cases understand that common lands are shared resources to be used by households, that is, a common pie to be divided by households (Table 2), as expressed by a commoner of $\mathrm{O}$ Carballo:

"People participate because they have the right to be part of the community, but they don't have a common goal...their goal is I am in the community because I take advantage of it at the individual level. That is the problem, and that's ... the key reason why it is so difficult to manage common lands, it's key to understand why they don't work, because ... people don't come together for a common goal, they come together because there are some possibilities that I can take advantage of a resource that exists at an individual level" commoner 1 (O Carballo common land, Galicia).

Assemblies and gatherings to organise and divide resource units are not sufficient to build the necessary community relations and the family remains the main social sphere of interaction as well as a primary unit for production and use of resources (e.g. grazing patches divided per family for production and use, mushroom picking or firewood). In these types of communities, legal commoners are keen on excluding other people to use the common land, as this would mean to divide the 'common pie' into smaller pieces (Table 2).

In these instances, we found that legal commoners experience conflictual relations among each other. For example, the case of $\mathrm{O}$ Carballo reveals conflictive and distrustful decision-making and management. This relates to the fact that the surplus of the common land is divided into equal parts (by households) in the form of money at the end of the year. Mistrust stems from the suspicion of unequal benefit sharing and disagreement about possible economic activities to increase the size of the pie. In other cases (Ansiães), legal commoners feel a disinterest to participate in collective activities because their lives are not linked to the common land. As expressed by a commoner in Ansiães:

"From the year 2000 on, we invested the earnings of the common land in a group of forest workers ...for bush cutting, maintenance of paths, fire-breaks... and now we have arrived at this situation ... do people need the common lands to live? I cannot say they need it. Today, their income does not come from the common land. People today are either retired or working for a company outside the parish or have a subsidy of some kind. The money that goes into our local communities is not money from the inside, it's from the outside. People have stopped depending on the common land as it was 100 years ago. Given the current situation, accelerated depopulation 
is occurring" - commoner 2 (Ansiães common land, North Portugal).

In these cases, the underlying subjectivity of separateness and independence among humans and with nature remains unchallenged and so sustainability outcomes can be questioned. Commoners relate to the common land for the subsistence of their family unit. They use the commonland individually, with family means- e.g. cattle and labour and sell the common resources to the market. The productive activities are usually subsidized, so commoners maintain a close relation to the market and the state.

As a consequence, social relatings are rather individualistic, or household-based, and market and state dependence dominate over horizontal relations among community members (Table 2). Activities organized at a community level are outsourced to payed workers and limited to industrial-like forestry activities- e.g. tree plantations and mechanical cleaning of the excess of biomass or opening of paths for machinery. As a result, sustainability can be considered at risk from a resilience perspective - e.g. the frequency and intensity of fires increases with large scale monospecific pine and eucalyptus plantations (Cordero Rivera, 2017), conflicts threaten resource governance and the continuity of community activities, and livelihoods are very instable due to market price instability which increases the risk of abandonment and emigration, as shown in the following:

"Everybody tells you that there are subsidies of one thing or another, but there is little real help. No one feels supported... Prices are very bad and, getting worse and then I don't know... For example, here there is no increase of prices of agricultural products, so the prices of what we produce does not increase ...There are the same prices as 25 or 30 years ago, but costs do increase every year, I have to adapt, but I adapt very badly" - commoner 3 (O Carballo common land, Galicia).

\subsubsection{Resources for the commons build an interdependent human community}

We define a second stage of commoning as characterized by a legal community forming an interdependent human community. This community structure is maintained when practices to use resources for the common dominate. We found that Ramallosa and, to some extent, $\mathrm{O}$ Carballo, had this structure. Beyond dividing the common land's economic surplus between households (O Carballo) or outsourcing collective work to payed workers (Ansiães), an interdependent human community involves a direct and more collective self-consumption of resources. In these cases, a multifunctional use of forests starts replacing monocultures, bringing back the model of the past, and replacing the industrial forestry model promoted by the state since the military regime. For example, the Ramallosa common land was covered by Eucalyptus plantations to supply the paper pulp industry. When legal commoners regained control, commoning involved recreating a multifunctional use of forests for the neighbours, as stated by an interviewee:

"We reduced the eucalyptus, we increased the hardwoods and pine, we took a step towards the use of the resin and the fruits of the common land, to maintain the honey, the mushrooms. There was an evolution from when the common land belonged to the state who cut the wood with roads and tracks, but we are on the path of a multifunctional common land. - commoner 4 (Ramallosa common land, Galicia).

In these cases, beyond general assemblies, the doings involved collective consumption of produced resources, as well as other social gatherings such as festivities and recreational activities in forests. For example, both Ramallosa and O Carballo started to organize an annual "Commoner's day", in which all commoners celebrated their belonging to the community and to the forest by being together with each other and the forest, by eating and dancing on the common land. In terms of sayings, commoners approach resources in their capacity to satisfy community needs, both material and cultural (Table 2). Practices of being together maintained networks of communication among community members, and generated the necessary interdependence, reciprocity and solidarity to manage resources in common. Thus, interdependent relatings between humans and nature dominated these cases, as shown below:

"We first promoted wood as an advantage for the neighbours. Everyone had the right to take a tractor full of firewood every year for their personal use. Honey production was understood as a product for the neighbours, not for sale, but we share all the honey we produce each year between us. Sometimes we have two kilos each, sometimes one... This creates a link, that is, people are thinking: I'm interested in the common land, because I benefit from it ... there's a relationship. After this we make popular festivals in the common land to enhance this feeling with the nature" - commoner 4 (Ramallosa common land, Galicia).

Although these communities still depend on markets, e.g. for selling wood or rents from leasing land for other productive uses, we consider multifunctionality as "an evolution" or change of paradigm and subjectivity: a change from an intensive forestry model to a model based on interdependent human communities that use multifunctional ecosystems to satisfy their needs. Furthermore, even though the law only recognises those officially living in the parish as legal commoners, and thus potential beneficiaries, we found that communities in these cases were keen to 'open' their common land to outsiders for trainings, social events, mushroom picking and recreation. These 'openings' came along with the creation of associations related to, but independent of, the common land formal organization. For example, O Carballo created a socio-cultural association to bypass the legal regulations to include activities beyond forestry activities and people beyond the parish inhabitants, as expressed by a member of O Carballo:

"There were certain things that we started to value, that were no longer directly related to the common land, right? There were cultural things and things that escaped a bit of the main goal of the management of the common land. So, we created a parallel cultural association, with a special connection with the theme of the common land $[\ldots]$ and nowadays we have more members from outside the parish than from the parish" - commoner 5 (O Carballo common land).

Thus, we found that when practices maintaining resources for the common dominate, inter-dependency among members of the legal community is strengthened reducing the individualistic relations, as shown below:

"If I tell the truth, I was a bit of a loner, an individualist. Since I came to be part of the common land I have learned a lot. [...] it has modified me, my personality. It has made me more concerned about people in general, and to do things that benefit my surroundings. When I first came it wasn't exactly like that. Because the world you live in doesn't exactly orient you to worry about your village, a place where you don't have your loved ones. So, the fact of entering the common land like this allows me to try to understand the significance of the community, and talk to people; one ends up having a relationship with people one barely knew- commoner 1 (O Carballo common land)

\subsubsection{Resources of the commons build a more-than-human community}

Commoning can also create more-than-human communities when practices to produce resources of the common dominate, as we found in Teis. Practices to produce resources "of the commons" include the regeneration and care of ecosystems and communities. Alternatively stated, the doings include regeneration through caring for others, ourselves and the environment (Euler, 2018; Tronto and Fisher, 1990) (Table 2). Teis' common lands' activities are focused on regenerating native forest ecosystems via removing invasive species and planting native flora. Beyond allowing the regeneration of habitats for native flora and fauna, the forest is considered a "regeneration site" for humans as well. Commoners believe that humans can "heal" only if they 
reconnect with their culture and with ecological processes; they promote this reconnection via educational activities, guided visits and the collaboration with a drug treatment and social reintegration centre, as expressed in the following:

[Name of a worker of the common land] came from [a drug treatment and social reintegration centre] and now this guy has been socially reinserted. I know he's a person who has been a drug addict, has tried everything but now he doesn't relapse ... he is like a consolidated area without acacias [an invasive tree], it does not matter if you abandon it, it works by itself, it regenerates itself. The common land has helped many people to get ahead, and the nature aspect is the most spectacular, to see how an area regenerates itself, once you have removed the acacias...to see the birth of the little cherry trees around here and ... the fauna comes along, spontaneously, they come from other places, they recolonize, that is the incredible thing! - commoner 6 (Teis common land)

We found that when focusing on regeneration, a new subjectivity emerged where the boundaries between humans and nature are blurred, a subjectivity of inter-being (Rauschmayer, 2017). Commoners become nature and feel that they belong to the common land, with its fauna and flora altogether, related and linked:

I break duality, I am nature, from the moment I hear "nature and us is not the same" I think this is a misappropriation. We are nature. Between me and an oak there is no difference, do you understand? The pure interdependence, I exist because that oak exists, myself does not end where my skin ends, that is a lie. So those oxygen molecules that enter your nostrils, are you or not? ... and the water of your blood? When that water is running through the rivers, is it not that same water as the $75 \%$ of water that forms your body?" - commoner 7 (Teis common land, Galicia)

Thus, we found that when commoning focuses on practices for the (re)production of the common (regeneration and care), it generates communities that are more-than-human. We see this change of subjectivity as transformative, as it challenges the logics of separateness and monetary relationships between humans and nature. The Teis case shows that this new subjectivity of inter-being brings forward new avenues for collective actions beyond sustainable ecosystem management: "we want to demonstrate that we can turn around the disastrous forest policies of the last 70 years" (commoner 7, Teis case). Here commoner 7 is referring to the regeneration of forests and communities that not only conserves the ecosystem, but is also intentioned to challenge the policies responsible for the expansion of (exotic and unmanaged) forest tree plantations, which have increased fire frequency, and eroded local culture and biodiversity (Cidrás et al., 2018; Serra et al., 2015). Commoner 7 states:

I believe that we [the Galicians] are very fortunate because within a hurricane of dehumanized capitalism, etc., here people gather, they make joint decisions, with a property system without a clear line of which square metre belongs to one or belongs to another but everything belongs to everyone, and that property is open, you can become a commoner, it is an incredible concept nowadays...And beyond that, it is more, it is about the forest, because if the native forest survives, we will survive - commoner 7 (Teis common land, Galicia).

\section{A research agenda to critically study human and more-than- human communities}

The liberal reform of the nineteenth and twentieth centuries has been responsible for the enclosures of common lands in Europe- e.g. the privatization or nationalization (Pemán and De Moor, 2013) - and for the commodification of common lands' resources - e.g. via the expansion of the belief that nature, knowledge, or other resources that were key for the material and cultural survival of communities can and should be trade for capital accumulation (Caffentzis and Federici, 2014; Capra and Mattei, 2015; Fournier, 2013). Thus, although some common lands have been devolved to local communities and even regulated by laws (Bravo and De Moor, 2008), many lack the practices sustaining human and more-than-human communities (e.g. García Quiroga, 2013; Grupo dos Comúns, 2006; Marey-Pérez et al., 2014, 2010). Forming communities, we argue, de-commodifies commons lands' resources "in the mind of people" (Fournier, 2013). As such this paper engages with the task of defining a research agenda and guiding framework for tackling what we think is an important challenge of today's historical commons: to understand and promote how legal commoners can start to feel and behave as part of human and more-than-human communities.

\subsection{A research agenda}

We call for embracing a CEC ontology to take a critical and political stance, and a CI epistemology that follows practices of institutional bricolage. The scale, rate and intensity of humans' impact on the planet urges for research into the historical commons to bring not only lessons for ecosystem management but also to engage with the systemic and cross-sectoral debate about transformations (Blythe et al., 2018; Göpel, 2016; O'Brien and Sygna, 2013; Popa et al., 2015). Researchers supporting transformations need a critical stance to produce knowledge counteracting hegemonic discourses and practices (Jhagroe, 2018). By studying how commoning processes manage to replace dominant logics of separateness to logics of human and more-than human communities, researchers can unveil and challenge the underlying reasons of the Anthropocene (Gibson-Graham and Roelvink, 2010). Our research agenda calls for critical action research projects (Jhagroe, 2018; Kemmis et al., 2014a) with an explicit normative positioning: promoting those sayings, doings and relatings underlying human and morethan-human communities (Table 2). This way, researchers, together with communities, can propose and devise ways to strengthen practices conducive to building more-than-human communities (Table 2).

Such a research agenda can benefit from a CI epistemology to critically understand commoning practices and outcomes in light of institutional bricolage (Cleaver, 2012). Commoning cannot change dominant practices strategically without critically taking into account the path-dependencies and history of the system. Commoners can be understood as "bricoleurs" who build on available resources (both material and immaterial) and recombine them in novel ways through the logic of dynamic adaptation and improvisation. As "bricoleurs", commoners aggregate, alter and articulate laws and other resources at hand (see De Koning and Cleaver, 2012). This implies that path-dependency and change co-exist, or in other words, that change always contains some degree of path dependency. Bricolage allows to critically explore path-dependency and change, and can be used by commoners and researchers as a heuristic to reflect upon commoning processes (Olsson et al., 2017). Commoning, as a bricolage process, tries to actively break from the path-dependence of the system.

\subsection{The guiding framework}

This section puts forward a guiding framework to study commoning as processes of bricolage. The framework provides an original commoning definition allowing critical explorations of commoning practices, proposes and defines three idealized stages of commoning and puts forward a hypothesis on how changes in subjectivities occur which portray historical commons as potential sites for nurturing transformation (Fig. 1).

Commoning is defined as practices organized by a distinct project. We have followed Kemmis et al.'s (2014b, a) characterization of practices, as formed by sayings, doings and relatings, to describe three stages of commoning in historical commons. Kemmis et al. (2014b,a) define a practice as a form of socially established cooperative human activity in which actions and activities (doings) are comprehensible in terms of characteristic discourses (sayings), whereby people and objects involved are distributed in characteristic relationships (relatings), and when this complex of sayings, doings and relatings 'hangs together' in a 


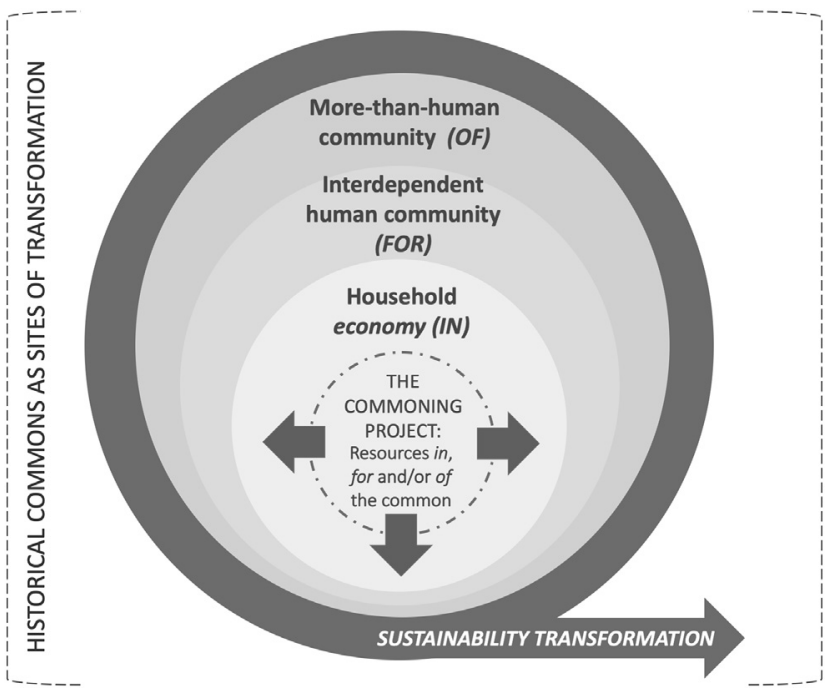

Fig. 1. Framework to study processes of building human and more-than-human communities. Historical legalised commons become sites to enhance sustainable transformation through commoning.

distinctive project (Kemmis et al., 2014b,a: 31). The project of a practice is whatever people answer to the question "what are you doing?" (Kemmis et al., 2014b: 31). This quality of 'hanging together' in a project is crucial for identifying the distinctiveness of particular kinds of practices (Kemmis et al., 2014b,a; 31). Following Kemmis et al. (2014b,a) and others, we define commoning as a type of practice composed by practices to share resources in, for and of the common (Fournier, 2013), with a distinctive project. This project is enhancing inter-dependency, creating an economy to satisfy community needs (human or/and more-than-human) and engaging in the ethical process of inclusively negotiating co-existence. Bearing this in mind, we define commoning in historical commons as the process by which members of the legal community voluntarily engage in practices to share resources in common, using them for the common, and/or producing resources of the common.

Contrarily to other definitions (e.g. Graham-Gibson, 2016; Bollier, 2016), we separate the elements of commoning practices (sayings, doings and relatings) to the project of the practice. As such, commoning practices (in, for and of) can be critically explored: are commoning practices reasonable and conducive to the intended and normative project? (see Kemmis et al., 2014a). Guiding questions to critically analyse commoning include: Which projects do legal commoners have? Which sayings, doings and relatings are organized around the different projects?

Three stages of commoning. Following Fournier (2013) the framework provides a model representing three stages of commoning in historical commons (Fig. 1). Each stage is dominated by specific practices defined by specific sayings, doings, and relatings, which are described in Table 2. The last stage is when legal communities build a more-than-human community, which challenges deeply the current subjectivity of separateness of the Anthropocene by bringing humans together with nature through negotiations of co-existence. This threestage model is an ideal one. In a real legal community, assemblages of different commoning practices (in, of and for the common) co-exist, and show contradictory aims and effects. Thus, within a legal community there are constellations of different types of communities (householdbased, interdependent human or more-than human). Yet, the ideal three stage model in Fig. 1 serves to compare the practices found in the legal community (the dominant sayings, doings and relatings) and critically assess how the commoning-community- i.e. the community relationally built through commoning negotiations (Fournier, 2013; Gibson-Graham et al., 2016a)- can practice bricolage to change dominant practices.

Historical commons as sites of transformation. In line with Singh, (2018), we define this type of property as "sites of transformation": places to cultivate more sustainable socio-economic paradigms, human-nature relations and subjectivities. Following the logic of bricolage, Fig. 1 assumes that legal communities are likely to evolve from the stage of household economies to human interdependent, and only then can they evolve to more-than-human communities (Fig. 1). For example, general assemblies to decide rules (resources in common), as well as collective consumption of resources (resources for the common) activate networks among the legal community. Only then can a legal community start forming an interdependent community (new relatings). Thereafter, through encounters with non-humans in collective work or other practices of being-in-common, the commoning-community can start feeling part of nature (Singh, 2018) (new sayings).

Following Fig. 1, researchers and commoners seeking transformations in a legal community dominated by household economies will have to firstly promote practices for the commons (encounters between humans, beyond decision making). Only when a human interdependent community is created, can one aim for including non-humans by promoting and strengthening practices of the common. Although it is out of the scope of this paper, we propose that ways to support this evolution as a researcher is to bring relations to other humans and non-humans to the fore of discussion and reflection, through mapping or other methodological devices (e.g. Duffy et al., 2018; Safri, 2015; Singh, 2018, 2013; Wright, 2015).

\section{Conclusion}

The study of historical commons has mainly looked at practices of decision-making to manage and use sustainable ecosystems (practices to share resources in common). However, we argue that the kind of contemporary challenges brought by the so-called era of the Anthropocene need a radical approach to commons research that goes beyond institutions and environmental sustainability. Humans need to re-connect to the biosphere (O'Brien and Sygna, 2013) and to learn to take non-humans into account when deciding future social developments (Gibson-Graham et al., 2016b). Hence, new socio-economic paradigms based on logics of inter-dependence and inter-being have to be nurtured (Gibson-Graham and Roelvink, 2010; Göpel, 2016; Rauschmayer, 2017). We believe that historical legalised commons can be sites for nurturing this type of transformation.

We have defined a research agenda building on a CEC ontology and a CI epistemology which focuses on the question: how does commoning build (or not) human and more-than human communities? And how can researchers support a process of (re)building communities that ends up including the more-than human world? For this, we provided a guiding framework for helping researchers implementing a critical and potentially transformative research agenda in historical commons. Our framework helps to further understand the type of practices involved in building human and more-than-human communities and thus, allowing transformative changes in subjectivities. Yet, we also call for actionresearch projects with experimental research methods that can enable transformative encounters between humans and non-humans. Only then can researchers of historical commons participate in challenging the deep structures of the Anthropocene. We hope our framework helps or inspires other researchers to go beyond institutional designs for environmental sustainability and helps historical commons to achieve their full potential as sites of transformation.

\section{Acknowledgements}

We are very grateful to all commoners that provided their time to this research. We acknowledge Angela Moriggi, Kelli Pearson, Katriina Soini and Talis Tisenkopfs for their comments on an early version, as well as to Bettina Bock who gave comments for the revision of the 
paper.

\section{Funding}

This project has received funding from the European Union's Horizon 2020 research and innovation programme under the Marie Skłodowska-Curie grant agreement No. 674962. Thanks are also due for the financial support to CESAM (UID/AMB/50017/2019), to FCT/ MCTES through national funds, and the cofunding by the FEDER, within the PT2020 Partnership Agreement and Compete 2020.

\section{Declaration of Competing Interest}

The authors declare no conflict of interest.

\section{References}

Agrawal, A., 2005. Environmentality. Curr. Anthropol. 46, 161-190. https://doi.org/10. $1086 / 427122$.

Alló, M., Loureiro, M.L., 2016. Evaluating the fulfillment of the principles of collective action in practice: a case study from Galicia (NW Spain). For. Policy Econ. 73, 1-9. https://doi.org/10.1016/j.forpol.2016.08.002.

Arts, B., Behagel, J., Koning, J., Turnhout, E., 2013. Forest and Nature Governance - A Practice Based Approach. Springer, World Forests XIV.

Baptista, F.O., 2010. O Espaço Rural. Declínio da Agricultura. Celta Editora.

Baptista, O., 2011. Os baldios. Autonomia e desenvolvimento local. In: 1o Congreasso Europeio Das Áreas Comunitárias, 23 e 24 Septembro 2011. BALADI, Vila Real, Portugal.

Barron, A., 2013. Free software production as critical social practice. Econ. Soc. 42, 597-625. https://doi.org/10.1080/03085147.2013.791510.

Blythe, J.L., Silver, J., Evans, L., Armitage, D., Bennett, N., Moore, M., Morrison, T.H., Brown, K., 2018. The dark side of transformation: latent risks in contemporary sustainability discourse Jessica. Antipode 50, 1206-1233. https://doi.org/10.1111/anti. 12405.

Bollier, D., 2016. Commoning as a transformative social paradigm. The Next System Project.

Bollier, D., 2014. Think like a Commoner. A Short Introduction to the Life of the Commons. New Society Publishers.

Bollier, D., Helfrich, S., 2015. Patterns of Commoning. The Commons Strategies Group in cooperation with Off the Common Books, Amherst, Massachusetts.

Bollier, D., Helfrich, S., 2012. The Wealth of the Commons: A World Beyond Market and State. The Commons Strategy Group.

Bradley, K., 2015. Open-Source Urbanism: Creating, Multiplying and Managing Urban Commons. FOOTPRINT 91-107. doi: 10.7480/footprint.9.1.901.

Bravo, G., De Moor, T., 2008. The commons in Europe: from past to future. Int. J. Commons 2, 155-161. https://doi.org/10.18352/ijc.98.

Bresnihan, P., 2015. The more-than-human commons: from commons to commoning. In: Kirwan, S., Dawney, L., Brigstocke, J. (Eds.), Space, Power and the Commons: The Struggle for Alternative Futures. Routledge, New York, pp. 20.

Bryden, J., Geisler, C., 2007. Community-based land reform: lessons from Scotland. Land Use Pol. 24, 24-34. https://doi.org/10.1016/j.landusepol.2005.09.004.

Caballero, G., 2015. Community-based forest management institutions in the Galician communal forests: a new institutional approach. For. Policy Econ. 50, 347-356. https://doi.org/10.1016/j.forpol.2014.07.013.

Caffentzis, G., Federici, S., 2014. Commons against and beyond capitalism. Commun. Dev. J. 49, i92-i105. https://doi.org/10.1093/cdj/bsu006.

Cameron, J., Gibson, K., Hill, A., 2014. Cultivating hybrid collectives: research methods for enacting community food economies in Australia and the Philippines. Local Environ. 19, 118-132. https://doi.org/10.1080/13549839.2013.855892.

Capra, F., Mattei, U., 2015. The Ecology of Law: Toward a Legal System in Tune With Nature and Community. Berett-Koehler Publishers, Inc. Currents Book.

Cidrás, D., Lois-González, R.-C., Paül, V., Cidrás, D., Lois-González, R.-C., Paül, V., 2018. Rural Governance against Eucalyptus Expansion in Galicia (NW Iberian Peninsula). Sustainability 10, 3396. https://doi.org/10.3390/su10103396.

Cleaver, F., 2012. Development Through Bricolage. Rethiking Institutions for Natural Resource Management, Routledge, London and New York.

Cleaver, F.D., De Koning, J., 2015. Furthering critical institutionalism. Int. J. Commons 9, 1. https://doi.org/10.18352/ijc.605.

Cleaver, F.D., Franks, T.R., 2005. How institutions elude design: river basin management and sustainable livelihoods. Bradford Centre for International Development. University of Bradford. Research Paper No.12: 1-21.

Cordero Rivera, A., 2017. Large scale eucalypt plantations associated to increased fire risk. PeerJ Prepr. 5. https://doi.org/10.7287/peerj.preprints.3348v1.

Cox, M., Arnold, G., Villamayor, S., 2010. A Review of Design Principles for Communitybased Natural Resource Management. Ecol. Soc. 15, 38. [online] URL: < http:// www.ecologyandsociety.org/vol15/iss4/art38/ > .

De Angelis, M., Harvie, D., 2014. The Commons. In: Parker, M., Cheney, G., Fournier, V., Land, C. (Eds.), The Routledge Companion to Alternative Organization, pp. 280-294.

De Koning, J., Cleaver, F., 2012. Institutional bricolage in community forestry: An agenda for future research. In: Van Bommel, S., Ros-Tonen, M.A.F., Verschoor, G.M., Arts, B.
(Eds.), Forest People Interfaces; Understanding Community Forestry and Biocultural Diversity. Publisher: Wageningen Academic Publishers. doi: 10.3920/978-90-8686749-3.

De Moor, T., 2011. Dossier « Le champ des commons en question: perspectives croisées »From common pastures to global commons: a historical perspective on interdisciplinary approaches to commons. Natures Sci. Sociétés 19, 422-431. https://doi. org $/ 10.1051 / \mathrm{nss} / 2011133$.

Diprose, G., 2016. Negotiating interdependence and anxiety in community economies, Environment and Planning A. Minneapolis. doi: 10.1177/0308518X16638659.

Diprose, G., Dombroski, K., Healy, S., Waitoa, J., 2017. Community economies: Responding to questions of scale, agency and indigenous connections in Aotearoa New Zealand. Counterfutures 167-183.

Diprose, K., 2015. Resilience is futile. Soundings 58, 44-56. https://doi.org/10.3898/ 136266215814379736.

Domínguez García, M.D., Swagemakers, P., Copena Rodríguez, D., Covelo Alonso, J., Simón Fernández, X., 2014. Collective agency and collaborative governance in managing the commons: the case of "A Serra do Galiñeiro" in Galicia, Spain. Spanish J. Rural Dev. V, 49-63.

Douglas, M.T., 1986. How Institutions Think. Syracuse University Press. Syracuse, New York. doi: $10.2307 / 2069673$.

Duffy, M., Gallagher, M., Waitt, G., 2018. Emotional and affective geographies of sustainable community leadership: a visceral approach. Geoforum. https://doi.org/10. 1016/J.GEOFORUM.2018.09.005.

Esteves, A.M., 2016. Radical Environmentalism and "Commoning”: Synergies Between Ecosystem Regeneration and Social Governance at Tamera Ecovillage, Portugal. Antipode. doi: 10.1111/anti.12278.

Euler, J., 2018. Conceptualizing the commons: moving beyond the goods-based definition by introducing the social practices of commoning as vital determinant. Ecol. Econ. 143, 10-16. https://doi.org/10.1016/j.ecolecon.2017.06.020.

Folke, C., 2006. Resilience: the emergence of a perspective for social-ecological systems analyses. Glob. Environ. Chang. 16, 253-267. https://doi.org/10.1016/j.gloenvcha. 2006.04.002.

Fournier, V., 2013. Commoning: on the social organisation of the commons. M@n@gement 4, 433-453. https://doi.org/10.3917/mana.164.0433.

García Quiroga, F., 2013. Desde la desarticulación al presente de los montes vecinales en mano común en Galicia. Teknokultura. Rev. Cult. Digit. y Movimientos Soc. 10, $155-176$.

Gibson-Graham, J.K., 2006. A Postcapitalist Politics. University of Minnesota Press.

Gibson-Graham, J.K., 1996. The End of Capitalism (As We Knew It): A Feminist Critique of Political Economy. University of Minnesota Press.

Gibson-Graham, J.K., Cameron, J., Healy, S., 2016a. Commoning as a postcapitalist politics. In: Amin, A., Howell, P. (Eds.), Releasing the Commons: Rethinking the Futures of the Commons. Routledge, pp. 192-212.

Gibson-Graham, J.K., Hill, A., Law, L., 2016b. Re-embedding economies in ecologies: resilience building in more than human communities. Build. Res. Inf. 44, 703-716. https://doi.org/10.1080/09613218.2016.1213059.

Gibson-Graham, J.K., Roelvink, G., 2010. An economic ethics for the anthropocene. Antipode 41, 320-346. https://doi.org/10.1002/9781444397352.ch15.

Goldman, M., 1998. Inventing the commons: theories and practices of the commons professional. Privatizing Nature: Political Struggles for the Global Commons. Pluto Press.

Gómez-Vázquez, I., Álvarez-Álvarez, P., Marey-Pérez, M.F., 2009. Conflicts as enhancers or barriers to the management of privately owned common land: a method to analyze the role of conflicts on a regional basis. For. Policy Econ. 11, 617-627. https://doi. org/10.1016/j.forpol.2009.09.001.

Göpel, M., 2016. The Great Mindshift. https://doi.org/10.1007/978-3-319-43766-8.

Grupo dos Comúns, 2006. Os montes Veciñais en Man Común. Xerais.

Hall, K., Cleaver, F., Franks, T., Maganga, F., 2013. Critical institutionalism: a synthesis and exploration of key themes (No. 63), Environment, Politics and Development Working Paper Series, Environment, Politics and Development Working Paper Series.

Haraway, D., 2010. When species meet: Staying with the trouble, Environment and Planning D: Society and Space. SAGE Publications. UK: London, England. doi: 10. 1068/d2706wsh.

Hardin, G.J., 1968. The tragedy of the commons. Science (80-.). 162, 8. doi: 10.1126/ science.162.3859.1243

Herman, A., 2016. 'More-than-human' resilience(s)? Enhancing community in Finnish forest farms. Geoforum 69, 34-43. https://doi.org/10.1016/j.geoforum.2015.12. 005 .

Jhagroe, S., 2018. Transition scientivism: on activist gardening and co- producing transition knowledge 'from below'. In: Bartels, K.P.R., Wittmayer, J.M. (Eds.), Action Research in Policy Analysis. Critical and Relational Approaches to Sustainability Transitions, London and New York.

Kaika, M., 2017. 'Don't call me resilient again!': the New Urban Agenda as immunology or what happens when communities refuse to be vaccinated with 'smart cities' and indicators. Environ. Urban. 29, 89-102. https://doi.org/10.1177/0956247816684763.

Kemmis, S., Mclaggart, R., Nixon, R., 2014a. The Action Research Planner. Doing Critical Participatory Action Research. Springer, Singapore Heidelberg New York Dordrecht London. doi: 10.1007/978-981-4560-67-2.

Kemmis, S., Wilkinson, J., Edwards-Groves, C., Hardy, I., Grooterboer, P., Bristol, L., 2014b. Changing Practices, Changing Education. Springer.

Kluvánková-Oravská, T., Chobotová, V., 2006. Shifting governance. Managing the commons: the case of Slovenský Raj National Park. Sociologia 38 (3), 221-244.

Lana, J.M., 2013. The "concurrence" and "hierarchization" of rights to property: the case of public lands in Spain. In: Beaur, G., Schofield, R., Chevet, J.M., Pérez-Picazo, T. (Eds.), Property Rights, Land Markets and Economic Growth in the European Countryside (Thirteenth-Twenteenth Centuries). Brepols, Turnhout, Belgium and 
COST, pp. 123-138.

Le Tourneau, F.-M., Beaufort, B., 2017. Exploring the boundaries of individual and collective land use management: institutional arrangements in the PAE Chico Mendes (Acre, Brazil). Int. J. Commons 11, 70. https://doi.org/10.18352/ijc.589.

Lejano, R., Castro, F., 2014. Social dimensions of the environment: the invisible hand of community. Environ. Sci. Policy 36, 73-85.

Lejano, R., Guo, J., Lian, H., Yon, B., 2018. A Phenomenology of Institutions: Relationality and Governance in China and. Routledge, Beyond.

Linebaugh, P., 2008. The Magna Carta Manifesto. Liberties and commons for all, Journal of Chemical Information and Modeling. University of California Press, California. doi: 10.1017/CBO9781107415324.004.

Lopes, J., 2008. Gestão dos terrenos comunitários do noroeste da península ibérica : muito estado e pouca participação. In: Congresso de Estudos Rurais (III CER). UAlg, Faro, Portugal.

Lopes, L.F., 2014. Advanced studies on mainland Portuguese common lands and forests. Universidade de Trás-os-Montes e Alto Douro.

Mantescu, L., Vasile, M., 2009. Property reforms in rural Romania and community-based forests. Rom. Sociol. 7, 95-113. doi:Editura Polirom.

Marey-Pérez, M.F., Calvo-González, A., Domínguez-Torres, G., 2014. Are the communal forest owners involved in the management of their lands?: A qualitative analysis for the case of Galicia (Spain). Bosque 35, 207-215. https://doi.org/10.4067/S071792002014000200008.

Marey-Pérez, M.F., Gómez-Vázquez, I., Díaz-Varela, E., 2010. Different approaches to the social vision of communal land management: the case of Galicia (Spain). Spanish J. Agric. Res. 8, 848. https://doi.org/10.5424/sjar/2010083-1287.

Mattei, U., 2012. First Thoughts for a Phenomenology of the Commons. Wealth Commons A Wolrd Beyond Mark. State.

McCay, B.J., Jentoft, S., 1998. Market or community failure? Critical perspectives on common property research. Hum. Organ. 57, 21-29. https://doi.org/10.17730/ humo.57.1.372712415k227u25.

Mcginnis, M.D., 2014. Social-Ecological System Framework : Initial Changes and Continuing Challenges Social-ecological system framework: initial changes and continuing 19. doi: 10.5751/ES-06387-190230.

Nightingale, A.J., 2011. Beyond design principles: subjectivity, emotion, and the (Ir)rational commons. Soc. Nat. Resour. 24, 119-132. https://doi.org/10.1080/ 08941920903278160

O’Brien, K., Sygna, L., 2013. Responding to Climate Change: The Three Spheres of Transformation. Proc. Transform. a Chang. Clim. Int. Conf. Oslo, 19-21 June 2013 $16-23$.

Olson, M., 1965. Logic of Collective Action: Public Goods and the Theory of Groups. Harvard University Press, Boston, MA.

Olsson, P., Gunderson, L., 2006. Shooting the rapids: navigating transitions to adaptive governance of social-ecological systems. Ecol. Soc. 11(1): 18. [online] URL: < http:// www.ecologyandsociety.org/vol11/iss1/art18/ >

Olsson, P., Moore, M.L., Westley, F.R., McCarthy, D.D.P., 2017. The concept of the Anthropocene as a game-changer: a new context for social innovation and transformations to sustainability. Ecol. Soc. 22. https://doi.org/10.5751/ES-09310-220231.

Ostrom, E., 2009. A general framework for analyzing sustainability of social-ecological systems. Science 325, 419-422. https://doi.org/10.1126/science.1172133.

Ostrom, E., 2005. Understanding Institutional Diversity. Princeton, NJ: Princeton Univ. Press, Princeton and Oxford. doi: 10.1017/CBO9781107415324.004.

Ostrom, E., 1990. Governing the Commons: The Evolution of Institutions for Collective Action. Cambridge University Press.

Paletto, A., de Meo, I., Ferretti, F., 2012. The influence of common property rights on forest management policy: a case study in Sardinia region, Italy. For. Stud./ Metsanduslikud Uurim. 56, 16-26. https://doi.org/10.2478/v10132-012-0002-8.

Parra, C., Walsh, C., 2016. Socialities of nature beyond Utopia. Nat. Cult. 11, 229-238. https://doi.org/10.3167/nc.2016.110301.

Pemán, M.L., De Moor, T., 2013. A tale of two commons. Some preliminary hypotheses on the long-term development of the commons in Western and Eastern Europe, 11th19th centuries. Int. J. Commons 7, 7-33. https://doi.org/10.18352/ijc.355.

Peters, P.E., 2004. Inequality and social conflict over land in Africa. J. Agrar. Chang. 4, 269-314. https://doi.org/10.1111/j.1471-0366.2004.00080.x.

Popa, F., Guillermin, M., Dedeurwaerdere, T., 2015. A pragmatist approach to transdisciplinarity in sustainability research. Futures 65, 45-56. https://doi.org/10.1016/j. futures.2014.02.002 T4 - From complex systems theory to reflexive science M4 Citavi.

Premrl, T., Udovč, A., Bogataj, N., Krč, J., 2015. From restitution to revival: A case of commons re-establishment and restitution in Slovenia. For. Policy Econ. 59, 19-26. https://doi.org/10.1016/j.forpol.2015.05.004.

Rauschmayer, F., 2017. Transition to Sustainability as Interbeing-or: from oncology to ontology. In: Meadowcroft, J., Banister, D., Holden, E., Langhelle, O., Linnerud, K., Gilpin, G. (Eds.), What Next for Sustainable Development? Our Common Future at Thirty, pp. 1-15.

Ribot, J.C., Peluso, N.L., 2009. A theory of access*. Rural Sociol. 68, 153-181. https:// doi.org/10.1111/j.1549-0831.2003.tb00133.x.

Rico Boquete, E., 1995. Política forestal e repoboacións en Galicia, 1941-1971. Universidade de Santiago de Compostela.

Roelvink, G., Gibson-Graham, J.K., 2009. A postcapitalist politcs of dwelling: ecological humanities and community economies in conversation. Aust. Humanit. Rev. 46, $145-158$.

Ruivenkamp, G., Hilton, A., 2012. Perspectives on commoning: autonomist principles and practices, pp. 1-19.

Safri, M., 2015. The Politics of Mapping Solidarity Economies and Diverse Economies in Brazil and the Northeastern United States. In: Roelvink, G., Martin, K. St., GibsonGraham, J.K. (Eds.), Making Other Possible Worlds. University of Minnessota Press, Minneapolis, pp. 296-321.

Sanchis-Ibor, C., Boelens, R., García-Mollá, M., 2017. Collective irrigation reloaded. Recollection and re-moralization of water management after privatization in Spain. Geoforum 87, 38-47. https://doi.org/10.1016/J.GEOFORUM.2017.10.002.

Sandström, E., Ekman, A.-K., Lindholm, K.-J., 2017. Commoning in the periphery ? The role of the commons for understanding rural continuities and change. Int. J. Commons 11, 508. https://doi.org/10.18352/ijc.729.

Saunders, F.P., 2014. The promise of common pool resource theory and the reality of commons projects. Int. J. Commons 8, 636-656. https://doi.org/10.18352/ijc.477.

Schatzki, T.R., Cetina, K.K., Von Savigny, E., 2001. The Practice Turn in Contemporary Theory. Routledge, London and New York.

Schlager, E., Ostrom, E., 1992. Property rights regimes and natural resources: a conceptual analysis. Land Econ. 68, 247-265. https://doi.org/10.2307/3146375.

Schlager, E., Ostrom, E., Economics, S.L., Aug, N., 1992. Property-Rights Regimes and Natural Resources: A Conceptual Analysis Property-Rights Regimes and Natural Resources: A Conceptual Analysis Edella Schlager and Elinor Ostrom property rights and the rules used to create $68,249-262$.

Serra, R., Barca, S. and Meira, T., 2015. Eucalyptus monoculture and common lands, Portugal [WWW Document]. Environ. Justice Atlas. URL < https://ejatlas.org/print/ eucalyptus-monoculture-and-common-lands-portugal $>$.

Singh, N.M., 2018. Becoming a commoner: the commons as sites for affective socio-nature encounters and co-becomings. Ephemer. Theory Polit. Organ. 17, 751-776.

Singh, N.M., 2013. The affective labor of growing forests and the becoming of environmental subjects: Rethinking environmentality in Odisha, India. Geoforum 47 189-198. https://doi.org/10.1016/j.geoforum.2013.01.010.

Sutcliffe, L., Paulini, I., Jones, G., Marggraf, R., Page, N., 2013. Pastoral commons use in Romania and the role of the Common Agricultural Policy. Int. J. Commons.

Swan, A., Cooper, N., 2013. Innovative funding methods for rural communities and their water pumps. Water Resour. Rural Dev. 1, 17-26. https://doi.org/10.1016/j.wrr. 2013.07.002.

Tronto, J.F., Fisher, B., 1990. Toward a feminist theory of caring. In: Abel, N.E., Nelson, M. (Eds.), Circles of Care.

Veiras, X., Soto, M.A., 2011. La conflictividad de las plantaciones de eucalipto en España (y Portugal). Análisis y propuestas para solucionar la conflictividad ambiental y social de las plantaciones de eucalipto en la península Ibérica. Greenpeace.

Vivero Pol, J.L., 2015. Transition towards a food commons regime: re-commoning food to crowd-feed the world. SSRN Electron. J 10.2139/ssrn.2548928.

Walker, B.H., Abel, N., Anderies, J.M., Ryan, P., 2009. Resilience, adaptability, and transformability in the Goulburn-Broken Catchment, Australia. Ecol. Soc. 1412

Whaley, L., 2018. The critical institutional analysis and development (CIAD) Framework. Int. J. Commons 12, 137-161. https://doi.org/10.18352/ijc.848.

Wright, S., 2015. More-than-human, emergent belongings. Prog. Hum. Geogr. 39 391-411. https://doi.org/10.1177/0309132514537132. 